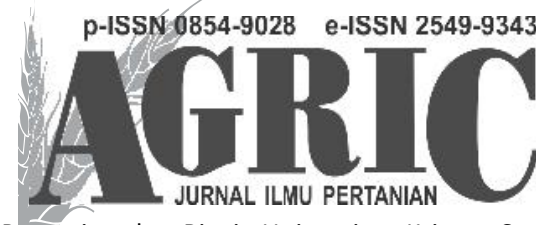

Fakultas Pertanian dan Bisnis Universitas Kristen Satya Wacana Jl. Diponegoro 52-60 SALATIGA 50711 - Telp. 0298-321212 ext 354

email: agric_fpb@yahoo.co.id, website: ejournal.uksw.edu/agric

\title{
UJI ADAPTASI VARIETAS UNGGUL BARU TERHADAP WERENG HIJAU DAN PENYAKIT TUNGRO DI KABUPATEN MERAUKE, PROVINSI PAPUA
}

\section{TEST OF NEWLY IMPROVED VARIETY ADAPTATION ON GREEN LEAFHOPPER AND TUNGRO DISEASE IN MERAUKE DISTRICT, PAPUA PROVINCE}

\author{
Sudarsono \\ Balai Pengkajian Teknologi Pertanian Papua \\ sudarsono2005@gmail.com \\ Dini Yuliani \\ Balai Besar Penelitian Tanaman Padi \\ diniyuliani2010@gmail.com
}

Diterima 6 Desember 2016, disetujui 31 Maret 2017

\begin{abstract}
Tungro is one of the important diseases in rice plants caused by two types of viruses were rod virus (rice tungro bacilliform virus) and spherical virus (rice tungro spherical virus) that was transmitted by the green leafhopper $(G L H)$ Nephotettix virescens. The purpose of this study to determine the adaptation of new improved varieties against GLH and tungro disease in Merauke, Papua Province. Research conducted at Tanah Miring District, Merauke, Papua Province between February and June 2010. The study was a randomized block design with three replications. The treatment consisted of 11 varieties, namely Inpari 1, Inpari 2, Inpari 3, Inpari 4, Inpari 5 Merawu, Inpari 6 Jete, Inpari 7 Lanrang, Inpari 8, Inpari 9 Elo, Inpari 10 Laeya, and Ciherang. Observations included the intensity of tungro and GLH population density at the age of rice plants of 1, 2, 3, and 4 weeks after planting (WAP). In addition, it was observed also the yield components of rice. The results showed that the GLH population density and the intensity of tungro disease was not significantly different at the 11 varieties tested. GLH attack had been found in 1 WAP with an average population density of 4.18 individual/20 single swing. GLH increases with the age of the rice crop with an average population density in 2 WAP (20 individual), 3 WAP (103.27 individual), and 4 WAP (154.15 individual) per 20 single swing. Tungro disease intensity in 11 varieties began were found in 3 WAP on average by $0.16 \%$ and increased at 4 WAP on average by $0.28 \%$. Varieties significant effect on yield components such as plant height, panicle length, number of total grain/panicle, percentage of filled grain, 1000 grain weight and productivity except the number of panicles/clump.
\end{abstract}

Keywords: Adaptation, New Varieties, Green Leafhopper, Tungro Disease, Merauke 


\begin{abstract}
ABSTRAK
Tungro merupakan salah satu penyakit penting tanaman padi yang disebabkan oleh dua jenis virus yaitu virus batang (rice tungro bacilliform virus) dan virus bulat (rice tungro spherical virus) yang ditularkan oleh wereng hijau Nephotettix virescens. Tujuan penelitian ini untuk mengetahui adaptasi varietas unggul baru terhadap serangan wereng hijau dan penyakit tungro di Kabupaten Merauke, Provinsi Papua. Penelitian dilaksanakan di Distrik Tanah Miring, Kabupaten Merauke, Provinsi Papua pada bulan Februari hingga Juni 2010. Penelitian menggunakan rancangan acak kelompok dengan tiga ulangan. Perlakuan terdiri atas 11 varietas yaitu Inpari 1, Inpari 2, Inpari 3, Inpari 4, Inpari 5 Merawu, Inpari 6 Jete, Inpari 7 Lanrang, Inpari 8, Inpari 9 Elo, Inpari 10 Laeya, dan Ciherang. Pengamatan meliputi intensitas serangan tungro dan kepadatan populasi wereng hijau pada umur tanaman padi 1, 2, 3, dan 4 minggu setelah tanam (MST). Selain itu, diamati juga komponen hasil padi. Hasil penelitian menunjukkan bahwa kepadatan populasi wereng hijau dan intensitas penyakit tungro tidak berbeda nyata pada 11 varietas uji. Serangan wereng hijau telah ditemukan pada 1 MST dengan kepadatan populasi rata-rata 4,18 individu/20 ayunan tunggal. Wereng hijau meningkat sejalan dengan bertambahnya umur tanaman padi dengan kepadatan populasi rata-rata pada 2 MST (20 individu), 3 MST (103,27 individu), dan 4 MST (154,15 individu) per 20 ayunan tunggal. Intensitas penyakit tungro pada 11 varietas mulai ditemukan pada 3 MST rata-rata sebesar $0,16 \%$ dan meningkat pada 4 MST sebesar 0,28\%. Varietas berpengaruh nyata terhadap komponen hasil diantaranya tinggi tanaman, panjang malai, jumlah gabah total/malai, persentase gabah isi, bobot 1000 butir, dan produktivitas hasil kecuali jumlah malai/rumpun.
\end{abstract}

Kata Kunci: Adaptasi, Varietas Unggul Baru, Wereng Hijau, Penyakit Tungro, Merauke

\section{PENDAHULUAN}

Penyakit tungro merupakan salah satu penyakit penting pada tanaman padi di Indonesia. Penyakit tungro dilaporkan endemis di sentra produksi padi di Pulau Jawa dan Provinsi Bali (Widiarta et al. 1997). Epidemi tungro sering terjadi hingga tahun 2000-an terutama di Sulawesi Selatan, Sulawesi Tengah, Bali, Nusa Tenggara Barat, Jawa Barat, Jawa Tengah, Jawa Timur, Banten, Lampung, dan Sumatera Utara yang merupakan sentra produksi padi (Raga, 2008). Serangan tungro diduga semakin meluas sebagai akibat penggunaan satu varietas secara terus menerus, tanpa pergiliran varietas yang mengakibatkan terjadinya proses adaptasi vektor atau mutasi virus sehingga wilayahwilayah tertentu menjadi daerah endemik baru penyakit tungro (Pakki dan Bastian, 2008).

Tungro merupakan penyakit padi disebabkan oleh dua jenis virus yaitu virus batang padi (rice tungro bacilliform virus, RTBV) dan virus bulat tungro padi (rice tungro spherical virus, RTSV), Kedua virus ditularkan secara semi persisten oleh beberapa spesies wereng hijau (Hibino dan Cabunagan, 1986), Penyakit ini ditularkan oleh spesies wereng hijau dengan efisiensi beragam, Nephotettix virescens merupakan vektor terpenting diantara keempat vektor lainnya karena memiliki efisiensi yang paling tinggi dalam menularkan virus tungro (Hibino and Cabunagan, 1986).

Tanaman padi yang terserang penyakit tungro memperlihatkan gejala yang khas, yakni perubahan warna daun muda menjadi kuning sampai jingga yang diikuti oleh melintirnya daun dan tanaman menjadi kerdil karena jarak antar buku (internode) memendek. Selain itu, jumlah anakan berkurang dan gabah akan berubah bentuk yang mengakibatkan tanaman tidak memberikan hasil sesuai dengan potensinya (Ling, 1979). Penyebaran penyakit tungro dapat meluas secara cepat terutama apabila faktorfaktor pendukung perkembangannya tersedia 
seperti kepadatan populasi vektor utama wereng hijau dan adanya sumber inokulum. Penanaman varietas padi yang rentan, dan pertanaman yang tidak serempak serta faktor lingkungan terutama musim hujan dan kelembaban yang tinggi, sangat menguntungkan bagi perkembangan wereng hijau.

Upaya pengendalian tungro telah banyak dilakukan, salah satu cara yang paling dianggap mudah dan murah yaitu penggunaan varietas tahan. Varietas tahan merupakan komponen pengendalian yang paling efektif untuk menekan kehilangan hasil akibat penyakit tungro (Sama, 1985), Oleh karena itu, usaha perbaikan dan perakitan varietas tahan tungro perlu dilakukan secara terus menerus untuk mendukung pergiliran varietas dalam rangka memperpanjang durasi ketahanan varietas. Pengujian ini bertujuan untuk mengevaluasi tingkat adaptasi varietas unggul baru padi terhadap serangan wereng hijau dan penyakit tungro di Kabupaten Merauke, Provinsi Papua.

\section{METODE PENELITIAN}

Penelitian dilaksanakan di Distrik Tanah Miring, Kabupaten Merauke, Propinsi Papua pada bulan Februari hingga Juni 2010. Penelitian menggunakan rancangan acak kelompok dengan tiga ulangan. Perlakuan terdiri atas 11 varietas yaitu Inpari 1, Inpari 2, Inpari 3, Inpari 4, Inpari 5 Merawu, Inpari 6 Jete, Inpari 7 Lanrang, Inpari 8, Inpari 9 Elo, Inpari 10 Laeya, dan Ciherang. Luas masing-masing petak percobaan adalah $7 \mathrm{~m} \mathrm{x} 4 \mathrm{~m}$. Penanaman varietas dalam bentuk pola tanam tegel $20 \mathrm{x}$ $20 \mathrm{~cm}$, menggunakan bibit umur 16 hari setelah semai. Jumlah bibit yang digunakan yaitu 1 hingga 2 batang per rumpun. Pemupukan dilakukan dengan menggunakan pupuk majemuk (NPK 15-15-15) dan urea dengan dosis masing-masing sebesar $300 \mathrm{~kg} / \mathrm{ha}$ dan $200 \mathrm{~kg} / \mathrm{ha}$.
Variabel pengamatan meliputi: intensitas serangan tungro (\%), dan kepadatan populasi wereng hijau (individu). Pengamatan intensitas serangan tungro dan kepadatan populasi wereng hijau dilakukan sebanyak empat kali yaitu 1, 2, 3, dan 4 minggu setelah tanam (MST). Pengamatan intensitas tungro dilakukan dengan mengamati keberadaan gejala tungro pada semua rumpun pada masing-masing petak pengamatan. Pengamatan kepadatan populasi wereng hijau dilakukan menggunakan jaring serangga dengan 20 kali ayunan tunggal pada setiap petak pengamatan. Hasil sweeping kemudian dibawa ke laboratorium untuk dihitung populasi wereng hijau yang diperoleh. Selain itu, diamati komponen hasil berupa tinggi tanaman maksimum (cm), jumlah malai/rumpun (batang), panjang malai $(\mathrm{cm})$, persentase gabah isi (\%), bobot 1.000 butir gabah (gram), jumlah gabah per rumpun (butir), produktivitas gabah kering giling pada kadar air 14\% (ton/ha). Persentase keberadaan tungro, kepadatan populasi wereng hijau, dan komponen hasil padi diuji sidik ragam dengan ANOVA. Perbedaan antar perlakuan dilanjutkan dengan uji DMRT pada taraf 5\% (Gomez and Gomez, 1984).

\section{HASIL DAN PEMBAHASAN}

\section{Agroklimat Penelitian}

Agroekosistem tanaman padi di Kabupaten Merauke merupakan sawah tadah hujan, sehingga waktu tanam sangat bergantung pada curah hujan di tempat tersebut. Pada umumnya hujan mulai turun pada bulan November hingga bulan-bulan berikutnya dan mencapai puncak pada bulan Januari hingga Februari (Gambar 1). Dengan kondisi tersebut menyebabkan penanaman padi hanya dilakukan sebanyak dua kali, yaitu di musim hujan dan musim kemarau. Secara umum, penanaman padi di musim hujan di mulai sejak bulan Desember hingga Januari di tahun berikutnya. Sedangkan penanaman di 
musim kemarau dimulai sejak bulan Mei hingga Juni, dengan perkiraan panen pada bulan September hingga Oktober. Pola tanam yang terbentuk adalah padi - padi, setelah tanam kedua di musim kemarau lahan tidak ditanami karena tidak tersedia air yang cukup untuk pertanaman. Keserempakan tanam hanya terjadi di sebagian tempat, namun di beberapa tempat ditemukan petani yang menanam padi lebih awal (mendahului).

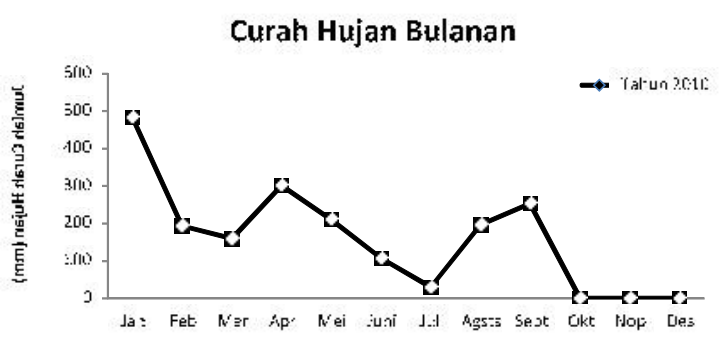

Gambar 1 Curah hujan bulanan (mm) di petak percobaan di Kabupaten Merauke MT 2010.

\section{Kepadatan Populasi Wereng Hijau}

Hasil analisis sidik ragam menunjukkan bahwa kepadatan populasi wereng hijau tidak berbeda nyata pada 11 varietas unggul baru (VUB) selama percobaan. Serangan wereng hijau telah ditemukan pada umur tanaman padi satu MST, dengan populasi wereng hijau relatif masih rendah rata-rata berkisar antara 3,00 hingga 6,33 individu/20 ayunan tunggal. Populasi wereng hijau pada satu MST terendah ditemukan pada varietas Inpari 10 Laeya, sedangkan populasi tertinggi pada varietas Inpari 1. Wereng hijau meningkat sejalan dengan bertambahnya umur tanaman padi dengan kepadatan populasi rata-rata berkisar antara 15,33 (Inpari 5) hingga 28,33 individu/ 20 ayunan tunggal (Inpari 9 Elo) pada dua MST (Tabel 1).

Peningkatan populasi wereng hijau yang cukup tajam terjadi pada umur padi tiga hingga empat MST. Populasi wereng hijau pada tiga MST terendah ditemukan pada varietas Ciherang dengan kepadatan rata-rata 87,33 individu/20 ayunan tunggal, sedangkan populasi tertinggi pada varietas Inpari 9 Elo dengan rata-rata 121 individu/20 ayunan tunggal. Pada empat MST, terjadi peningkatan populasi wereng hijau sebesar 53 hingga $82 \%$. Populasi wereng hijau pada empat MST terendah ditemukan pada varietas Inpari 6 Jete dengan kepadatan ratarata 118,33 individu/20 ayunan tunggal, sedangkan populasi tertinggi pada varietas Inpari 4 dengan rata-rata 220 individu/20 ayunan tunggal (Tabel 1). Tingginya populasi wereng hijau pada umur tiga hingga empat MST, bertepatan dengan curah hujan bulanan pada bulan Maret hingga Juni 2010 mengalami peningkatan berkisar antara 200 hingga 300 mm (Gambar 1). Hal ini sejalan dengan hasil penelitian Pakki (2010), bahwa semakin tinggi curah hujan diikuti oleh tingginya populasi wereng hijau.

Meskipun curah hujan lebih rendah dari tahun sebelumnya (Lestari dan Sudarsono, 2011), namun populasi wareng hijau yang ditemukan di lapangan sangat tinggi. Hal ini menunjukkan bahwa tingkat kepadatan populasi wereng hijau di lapangan tidak hanya bergantung pada curah hujan namun juga dipengaruhi oleh faktor lain seperti, gulma sekitar lahan, cara pengendalian, penggunaan pestisida, kehadiran musuh alami. Meskipun demikian terlihat pola awal kehadiran wereng hijau, peningkatan populasi, dan puncak populasi, informasi ini berguna sebagai strategi pengendalian tungro, dengan pendekatan penanaman waktu yang tepat sebelum puncak populasi vektor virus tungro yaitu wereng hijau.

\section{Intensitas Penyakit Tungro}

Hasil analisis sidik ragam menunjukkan bahwa intensitas penyakit tungro tidak berbeda nyata pada 11 varietas uji. Intensitas penyakit tungro pada 11 varietas mulai ditemukan pada tiga MST rata-rata sebesar $0,16 \%$ dan meningkat 
Tabel 1 Kepadatan populasi wereng hijau pada varietas unggul baru. Merauke. MT 2010

\begin{tabular}{lllll}
\hline \multirow{2}{*}{ Varietas } & \multicolumn{4}{c}{ Populasi Wereng Hijau/20 ayunan tunggal } \\
\cline { 2 - 5 } & $1 \mathrm{MST}$ & $2 \mathrm{MST}$ & $3 \mathrm{MST}$ & 4 MST \\
\hline Inpari 1 & $6,33 \mathrm{a}$ & $16,67 \mathrm{~b}$ & $89,00 \mathrm{a}$ & $148,67 \mathrm{a}$ \\
Inpari 2 & $3,67 \mathrm{a}$ & $18,67 \mathrm{ab}$ & $101,67 \mathrm{a}$ & $130,33 \mathrm{a}$ \\
Inpari 3 & $3,33 \mathrm{a}$ & $19,00 \mathrm{ab}$ & $93,00 \mathrm{a}$ & $128,00 \mathrm{a}$ \\
Inpari 4 & $5,00 \mathrm{a}$ & $21,67 \mathrm{ab}$ & $115,67 \mathrm{a}$ & $220,00 \mathrm{a}$ \\
Inpari 5 Merawu & $4,00 \mathrm{a}$ & $15,33 \mathrm{~b}$ & $111,33 \mathrm{a}$ & $153,33 \mathrm{a}$ \\
Inpari 6 Jete & $4,33 \mathrm{a}$ & $20,33 \mathrm{ab}$ & $96,67 \mathrm{a}$ & $118,33 \mathrm{a}$ \\
Inpari 7 Lanrang & $5,00 \mathrm{a}$ & $17,67 \mathrm{ab}$ & $109,67 \mathrm{a}$ & $160,00 \mathrm{a}$ \\
Inpari 8 & $4,33 \mathrm{a}$ & $20,67 \mathrm{ab}$ & $103,33 \mathrm{a}$ & $132,67 \mathrm{a}$ \\
Inpari 9 Elo & $3,67 \mathrm{a}$ & $28,33 \mathrm{a}$ & $121,00 \mathrm{a}$ & $180,33 \mathrm{a}$ \\
Inpari 10 Laeya & $3,00 \mathrm{a}$ & $23,67 \mathrm{ab}$ & $107,33 \mathrm{a}$ & $166,67 \mathrm{a}$ \\
Ciherang & $3,33 \mathrm{a}$ & $19,00 \mathrm{ab}$ & $87,33 \mathrm{a}$ & $157,33 \mathrm{a}$ \\
\hline
\end{tabular}

Angka yang diikuti oleh huruf yang sama tidak berbeda nyata pada uji DMRT taraf $5 \%$.

pada empat MST rata-rata sebesar 0,28\%. Pada umur padi satu hingga dua MST tidak diperoleh intensitas serangan tungro, meskipun populasi wereng hijau cukup tinggi (Tabel 2). Hal ini diduga tidak adanya sumber inokulum tungro pada awal fase vegetatif tanaman padi di sekitar petak pengamatan.

Wereng hijau telah ditemukan di lahan sejak awal pengamatan, dan kepadatan populasi meningkat seiring dengan pertumbuhan tanaman padi. Meskipun populasi wereng hijau tinggi namun insiden penyakit tungro yang ditemukan sangat rendah, dibawah $0.6 \%$ hingga akhir pengamatan. Varietas ciherang sebagai kontrol menunjukkan gejala tungro yang sangat rendah, meskipun ditanam pada waktu waktu tanam yang terlambat. Hal ini berbeda dengan hasil penelitian Lestari dan Sudarsono (2011), bahwa penanaman padi di waktu tersebut akan berpotensi terserang tungro dan menyebabkan kehilangan hasil padi. Meskipun imigrasi dan perkembangan populasi wereng hijau di awal musim tanam dipengaruhi oleh penyebaran tungro, namun tidak ada hubungan yang konsisten antara kelimpahan wereng dan kejadian penyakit (Chancellor et al. 1996).

Tabel 2 Intensitas penyakit tungro pada varietas unggul baru. Merauke. MT 2010.

\begin{tabular}{lllll}
\hline \multirow{2}{*}{ Varietas } & \multicolumn{4}{c}{ Intensitas Penyakit Tungro (\%) } \\
\cline { 2 - 5 } & $1 \mathrm{MST}$ & $2 \mathrm{MST}$ & $3 \mathrm{MST}$ & $4 \mathrm{MST}$ \\
\hline Inpari 1 & $0,00 \mathrm{a}$ & $0,00 \mathrm{a}$ & $0,52 \mathrm{a}$ & $0,57 \mathrm{a}$ \\
Inpari 2 & $0,00 \mathrm{a}$ & $0,00 \mathrm{a}$ & $0,09 \mathrm{ab}$ & $0,48 \mathrm{a}$ \\
Inpari 3 & $0,00 \mathrm{a}$ & $0,00 \mathrm{a}$ & $0,00 \mathrm{~b}$ & $0,04 \mathrm{a}$ \\
Inpari 4 & $0,00 \mathrm{a}$ & $0,00 \mathrm{a}$ & $0,35 \mathrm{ab}$ & $0,48 \mathrm{a}$ \\
Inpari 5 Merawu & $0,00 \mathrm{a}$ & $0,00 \mathrm{a}$ & $0,00 \mathrm{~b}$ & $0,09 \mathrm{a}$ \\
Inpari 6 Jete & $0,00 \mathrm{a}$ & $0,00 \mathrm{a}$ & $0,13 \mathrm{ab}$ & $0,31 \mathrm{a}$ \\
Inpari 7 Lanrang & $0,00 \mathrm{a}$ & $0,00 \mathrm{a}$ & $0,00 \mathrm{~b}$ & $0,35 \mathrm{a}$ \\
Inpari 8 & $0,00 \mathrm{a}$ & $0,00 \mathrm{a}$ & $0,26 \mathrm{ab}$ & $0,26 \mathrm{a}$ \\
Inpari 9 Elo & $0,00 \mathrm{a}$ & $0,00 \mathrm{a}$ & $0,00 \mathrm{~b}$ & $0,00 \mathrm{a}$ \\
Inpari 10 Laeya & $0,00 \mathrm{a}$ & $0,00 \mathrm{a}$ & $0,26 \mathrm{ab}$ & $0,30 \mathrm{a}$ \\
Ciherang & $0,00 \mathrm{a}$ & $0,00 \mathrm{a}$ & $0,17 \mathrm{ab}$ & $0,23 \mathrm{a}$ \\
\hline
\end{tabular}

Angka yang diikuti oleh huruf yang sama tidak berbeda nyata pada uji DMRT taraf 5\%. 
Kemungkinan lain rendahnya intensitas tungro yaitu virus yang menyerang adalah virus tunggal RTSV atau RTBV. Menurut Rahim dan Nasrudin (2010), umumnya tanaman padi yang terinfeksi RTSV secara tunggal tidak menghasilkan gejala penyakit yang jelas. Tanaman padi yang terinfeksi RTBV secara tunggal akan menghasilkan gejala yang ringan. Namun bilamana terinfeksi oleh kedua virus yaitu RTBV dan RTSV maka tanaman padi akan memperlihatkan gejala kerdil, anakan berkurang, daun menjadi diskolorasi menjadi kuning hingga jingga atau kemerah-merahan, dan diikuti oleh munculnya bercak-bercak coklat seperti karat.

Varietas berpengaruh nyata terhadap komponen hasil diantaranya tinggi tanaman, panjang malai, jumlah gabah total/malai, persentase gabah isi, bobot 1000 butir, dan produktivitas hasil kecuali jumlah malai/rumpun (Tabel 3 dan 4). Tinggi tanaman VUB yang ditanam di Kabupaten Merauke memiliki tinggi tanaman yang lebih tinggi dengan rata-rata kisaran 115,24 hingga $139,20 \mathrm{~cm}$ dibandingkan deskripsi varietas padi yaitu kisaran 85 hingga $120 \mathrm{~cm}$. Varietas Inpari 6 Jete, Inpari 8, Inpari 9Elo, dan Ciherang memiliki postur yang lebih tinggi dibandingkan varietas lainnya. Jumlah malai per rumpun tertinggi dijumpai pada Inpari 9 Elo dan Inpari 10 Laeya, sedangkan terendah pada varietas Inpari 6 Jete. Ciherang memiliki malai terpanjang yaitu $29,16 \mathrm{~cm}$, sedangkan Inpari 2 memiliki malai terpendek yaitu 22,79 $\mathrm{cm}$. Jumlah gabah total per malai tertinggi ditemukan pada plot Inpari 8 dan Inpari 9 Elo masing-masing sebesar 180,67 dan 175 butir (Tabel 3).

Persentase gabah isi tertinggi ditemukan pada varietas Inpari 7 Lanrang (85,32\%), Inpari 9 Elo $(83,23 \%)$, dan Inpari 10 Laeya $(83,68 \%)$. Sedangkan persentase gabah isi terendah ditemukan pada varietas Inpari 5 Merawu sebesar 63,38\%. Bobot 1000 butir tertinggi diperoleh pada plot Inpari 6 Jete sebesar 30,90 gram, sedangkan terendah dijumpai pada plot Inpari 8 dan Inpari 9 Elo. Terdapat enam varietas yang memiliki bobot 1000 butir lebih rendah dibandingkan deskripsi varietas padi yaitu Inpari 1, Inpari 2, Inpari 4, Inpari 7 Lanrang, Inpari 9 Elo, dan Ciherang. Varietas Inpari 3, Inpari 5 Merawu, dan Inpari 6 Jete memiliki bobot 1000 butir relatif lebih tinggi dibandingkan deskripsi varietas padi. Sedangkan varietas yang memiliki bobot 1000 butir yang sama dengan deskripsi varietas padi yaitu Inpari 8 dan Inpari 10 Laeya (Tabel 4).

Tabel 3 Tinggi tanaman, jumlah malai per rumpun, panjang malai, jumlah gabah total per malai. Merauke. MT 2010

\begin{tabular}{lllll}
\hline Varietas & $\begin{array}{l}\text { Tinggi } \\
\text { Tanaman } \\
(\mathrm{cm})\end{array}$ & $\begin{array}{l}\text { Jumlah } \\
\text { Malai/Rumpun } \\
\text { (batang) }\end{array}$ & $\begin{array}{l}\text { Panjang Malai } \\
(\mathrm{cm})\end{array}$ & $\begin{array}{l}\text { Jumlah Gabah } \\
\text { Total/malai } \\
(\mathrm{butir})\end{array}$ \\
\hline Inpari 1 & $117,60 \mathrm{cb}$ & $15,13 \mathrm{ab}$ & $24,73 \mathrm{~cd}$ & $116,67 \mathrm{~d}$ \\
Inpari 2 & $115,24 \mathrm{c}$ & $15,31 \mathrm{ab}$ & $22,79 \mathrm{e}$ & $82,67 \mathrm{e}$ \\
Inpari 3 & $122,51 \mathrm{~b}$ & $15,80 \mathrm{ab}$ & $24,06 \mathrm{~d}$ & $126,67 \mathrm{~cd}$ \\
Inpari 4 & $122,89 \mathrm{~b}$ & $14,64 \mathrm{ab}$ & $25,18 \mathrm{bcd}$ & $118,00 \mathrm{~d}$ \\
Inpari 5 Merawu & $117,02 \mathrm{bc}$ & $14,31 \mathrm{ab}$ & $25,92 \mathrm{bc}$ & $140,33 \mathrm{bcd}$ \\
Inpari 6 Jete & $137,84 \mathrm{a}$ & $13,62 \mathrm{~b}$ & $25,59 \mathrm{bc}$ & $154,33 \mathrm{abc}$ \\
Inpari 7 Lanrang & $122,84 \mathrm{~b}$ & $15,51 \mathrm{ab}$ & $25,30 \mathrm{bcd}$ & $124,33 \mathrm{~d}$ \\
Inpari 8 & $133,89 \mathrm{a}$ & $16,51 \mathrm{ab}$ & $26,33 \mathrm{~b}$ & $180,67 \mathrm{a}$ \\
Inpari 9 Elo & $137,11 \mathrm{a}$ & $17,24 \mathrm{a}$ & $25,51 \mathrm{bc}$ & $175,00 \mathrm{a}$ \\
Inpari 10 Laeya & $120,22 \mathrm{bc}$ & $16,87 \mathrm{a}$ & $24,80 \mathrm{~cd}$ & $115,33 \mathrm{~d}$ \\
Ciherang & $139,20 \mathrm{a}$ & $16,33 \mathrm{ab}$ & $29,16 \mathrm{a}$ & $163,00 \mathrm{ab}$ \\
\hline
\end{tabular}

Angka yang diikuti oleh huruf yang sama tidak berbeda nyata pada uji DMRT taraf $5 \%$. 
Tabel 4 Presentase gabah isi, bobot 1000 butir, dan produktivitas hasil. Merauke. MT 2010.

\begin{tabular}{llll}
\hline Varietas & $\begin{array}{l}\text { Persentase Gabah } \\
\text { Isi }(\%)\end{array}$ & $\begin{array}{l}\text { Bobot } 1000 \\
\text { Butir }(\mathrm{gr})\end{array}$ & $\begin{array}{l}\text { Produktivitas } \\
\text { Hasil (t/ha) }\end{array}$ \\
\hline Inpari 1 & $76,80 \mathrm{abcd}$ & $25,93 \mathrm{c}$ & $6,41 \mathrm{abc}$ \\
Inpari 2 & $70,70 \mathrm{cde}$ & $25,13 \mathrm{c}$ & $5,83 \mathrm{~cd}$ \\
Inpari 3 & $81,07 \mathrm{abc}$ & $26,10 \mathrm{c}$ & $6,25 \mathrm{bc}$ \\
Inpari 4 & $82,20 \mathrm{ab}$ & $24,67 \mathrm{c}$ & $6,87 \mathrm{ab}$ \\
Inpari 5 Merawu & $63,38 \mathrm{e}$ & $29,13 \mathrm{~b}$ & $5,03 \mathrm{~d}$ \\
Inpari 6 Jete & $72,47 \mathrm{cde}$ & $30,90 \mathrm{a}$ & $6,19 \mathrm{bc}$ \\
Inpari 7 Lanrang & $85,32 \mathrm{a}$ & $25,73 \mathrm{c}$ & $7,12 \mathrm{ab}$ \\
Inpari 8 & $69,89 \mathrm{de}$ & $22,90 \mathrm{~d}$ & $6,61 \mathrm{abc}$ \\
Inpari 9 Elo & $83,23 \mathrm{a}$ & $22,40 \mathrm{~d}$ & $7,27 \mathrm{a}$ \\
Inpari 10 Laeya & $83,68 \mathrm{a}$ & $27,87 \mathrm{~b}$ & $6,43 \mathrm{abc}$ \\
Ciherang & $70,53 \mathrm{cde}$ & $26,00 \mathrm{c}$ & $6,67 \mathrm{abc}$ \\
\hline
\end{tabular}

Angka yang diikuti oleh huruf yang sama tidak berbeda nyata pada uji DMRT taraf $5 \%$.

Produktivitas hasil tertinggi dijumpai pada varietas Inpari 9 Elo sebesar 7,27 ton/ha. Menurut Suprihatno et al. (2010), rata-rata hasil varietas Inpari 9 Elo sebesar 6,25 ton/ha. Hal ini menunjukkan Kabupaten Merauke merupakan lahan yang subur dan berpotensi untuk dijadikan sentra produksi padi nasional. Produktivitas hasil terendah dijumpai pada varietas Inpari 5 Merawu sebesar 5,03 ton/ha dan relatif lebih kecil dibandingkan dengan ratarata hasil berdasarkan deskripsi varietas padi (5,74 ton/ha). Terdapat empat varietas yang memiliki produktivitas hasil lebih rendah dibandingkan deskripsi varietas padi yaitu Inpari 1, Inpari 5 Merawu, Inpari 6 Jete, dan Inpari 10 Laeya. Varietas Inpari 3, Inpari 4, Inpari 7 Lanrang, Inpari 8, Inpari 9 Elo, dan Ciherang memiliki produktivitas hasil relatiflebih tinggi dibandingkan deskripsi varietas padi. Sedangkan varietas yang memiliki bobot 1000 butir yang sama dengan deskripsi varietas padi yaitu Inpari 2 (Tabel 4).

Produksi varietas Inpari 7 (7,12 ton/ha) dan Inpari 9 (7,27 ton/ha) menunjukkan hasil yang lebih tinggi dibandingkan varietas uji lainnya dan sangat berpotensi dikembangkan untuk kawasan pangan Kabupaten Merauke, Propinsi Papua. Hal ini sejalan dengan hasil penelitian Pakki (2010), bahwa Inpari 7 dan
Inpari 9 mempunyai prospek dikembangkan pada wilayah-wilayah endemis tungro, sifat tahan terhadap tungro dengan produksi sekitar 6,3 dan 6,83 ton/ha.

Meskipun sebagian besar varietas menunjukkan gejala penyakit tungro, namun tidak memperlihatkan pengaruh yang nyata terhadap produksi maupun komponen hasil lainnya. Hal ini disebabkan karena waktu awal kemunculan gejala penyakit di pertanaman baru terlihat setelah umur padi 3 MST dan intensitas penyakit tungro tergolong rendah (Tabel 2). Hal ini menjadi dugaan bahwa infeksi virus tungro terjadi setelah tanam pindah. Intensitas penyakit tungro yang rendah memungkinkan proses fisiologi tanaman terus berlangsung dan tidak berpengaruh nyata terhadap komponen hasil, sehingga tanaman masih dapat tumbuh dengan optimum.

Dari hasil penelitian ini belum dapat ditarik kesimpulan secara umum varietas apa yang masuk dalam kategori toleran atau tahan terhadap penyakit tungro untuk wilayah tersebut. Hal ini disebabkan pada varietas Ciherang sebagai varietas cek, hingga akhir pengamatan tidak memperlihatkan intensitas penyakit tungro yang tinggi. Berbeda dengan yang dilaporkan oleh Lestari dan Sudarsono 
(2011), bahwa varietas Ciherang merupakan varietas yang rentan. Meskipun belum terlihat varietas yang toleran, namun sebagian besar varietas berpotensi untuk dikembangkan di wilayah tersebut, terlihat dari produksi yang tinggi (Tabel 4) diatas rata-rata produksi petani. Inpari 7, Inpari 8, dan Inpari 9 merupakan varietas yang perlu mendapat perhatian dalam pengembangannya, karena memiliki potensi produksi gabah yang tinggi, lebih tinggi dari hasil yang diperoleh dari daerah Jayapura (Merlin dan Kasim, 2011) dan daerah Wajo (Arafah 2011). Selain itu, varietas tersebut juga memiliki karakteristik tahan tungro sebagai salah salah satu alasan utama pelepasan varietas (Jamil et al. 2015). Dalam upaya pengembangan varietas tersebut, harus memperhatikan kondisi biofisik lainnya, serta melakukan pengendalian hama dan penyakit secara terpadu.

Varietas Inpari 7, Inpari 8, dan Inpari 9 dapat menggantikan varietas yang telah existing namun telah rentan terhadap Organisme Pengganggu Tanaman (OPT) setempat. Menurut Skelsey et al. (2005), diversifikasi varietas tahan dengan latar belakang genetik yang berbeda menjadi komponen penting dalam keberhasilan pengendalian suatu patogen yang berkelajutan baik melalui pergiliran varietas maupun penanaman multi-varietas tahan di suatu wilayah.

Populasi wereng hijau di Kabupaten Merauke menunjukkan kepadatan cukup tinggi, namun tidak berkorelasi positif dengan intensitas penyakit tungro yang rendah. Hal ini dapat disimpulkan bahwa epidemik penyakit tungro di Kabupaten Merauke tergolong rendah. Keragaman virulensi virus tungro dan tekanan seleksi koloni wereng hijau merupakan kompleksitas penyebab terjadinya epidemik penyakit tungro. Ketahanan suatu varietas sangat berperan dalam perkembangan epidemik penyakit tungro (Pakki dan Bastian, 2008).

Pengendalian penyakit tungro harus dilakukan secara komprehensif dengan memperhatikan berbagai aspek seperti tingkat ketahanan varietas, kepadatan wereng hijau dan efisiensi wereng hijau, penyebaran virus, ketersediaan sumber inokulum, kondisi lingkungan dan sosial ekonomi petani (Praptana dan Burhanuddin, 2008). Implikasi strategi pengendalian penyakit tungro berdasarkan dinamika populasi wereng hijau pada pola tanam padi-padi-padi ditargetkan untuk mengurangi kemampuan pemerolehan dan penularan virus guna meminimalkan efek negatif pemencaran imago (Widiarta et al. 1999). Penyebaran dan perkembangan tungro di Indonesia merupakan salah satu informasi penting dalam pengelolaan penyakit tungro. Dalam rangka kegiatan $\mathrm{P} 2 \mathrm{BN}$, diperlukan informasi dalam penentuan lokasi pengembangan produksi khususnya yang berkaitan dengan introduksi padi terhadap OPT setempat. Hal tersebut diperlukan juga dalam rangka menyusun strategi dan perencanaan dalam pengawalan pertanaman dari serangan OPT (Raga, 2008).

\section{KESIMPULAN}

Kepadatan populasi wereng hijau dan intensitas penyakit tungro tidak berbeda nyata pada 11 varietas uji (Inpari 1 hingga Inpari 10 dan Ciherang). Tingginya kepadatan populasi wereng hijau dilahan bukan merupakan faktor utama dan tunggal terhadap munculnya intensitas penyakit tungro. Faktor virulensi dan jenis virus tungro yang menyerang tanaman padi, cara bududaya setempat, serta faktor lingkungan (agroklimat) mempengaruhi intensitas penyakit tungro di lahan percobaan. Sebagian besar varietas unggul baru yang diuji berpotensi untuk dikembangkan di kawasan Kabupaten Merauke, Provinsi Papua. 


\section{DAFTAR PUSTAKA}

Arafah. 2011. Uji Adaptasi Beberapa Varietas Unggul Baru Padi di Kecamatan Takkalalla Kabupaten Wajo. Dalam Rauf A.W., R. Hendayana, E. Sutisna, Atekan, S. Ruku. Seminar Nasional Akselerasi Pembangunan Pertanian dan Perdesaan Berbasis Inovasi dan Sumberdaya Lokal. 28 September 2011. Manokwari, ID. Bogor (ID): Balai Besar Pengkajian dan PengembanganTeknologi Pertanian. Hal: 221-223.

Chancellor, T.C.B., P.S. Teng, and K.L. Heong. 1996. Rice tungro disease epidemiology and vector ecology. IRRI Discussion Paper Series No. 19: Int. Rice Res. Inst. Los Banos.

Gomez, A.K. and A.A. Gomez. 1995. Prosedur Statistika Untuk Penelitian Pertanian. (Terjemahan oleh Enang Sjamsudin \& Justika Baharsjah). Edisi 11. UI Press, Jakarta. 698 Hal.

Hibino, H. and R.C. Cabunagan. 1986. Rice tungro associated viruses and their relation to host plants and vector leafhopper. Trop. Agric. Res. Ser. 19: 173-182.

Jamil A., Satoto, P. Sasmita, A. Guswara, Suharna. 2015. Deskripsi Varietas Unggul Baru. Balai Besar Penelitian Tanaman Padi. Sukamandi (ID). Badan Penelitian dan Pengembangan Pertanian.

Lestari MS dan Sudarsono. 2011. Pengendalian penyakit tungro melalui introduksi galur/ varietas dan pengaturan waktu tanam pada daerah endemik di Kabupaten Merauke Papua. Dalam Rauf A.W., R. Hendayana, E. Sutisna, Atekan, S. Ruku. SeminarNasional Akselerasi Pembangunan Pertanian dan Perdesaan Berbasis Inovasi dan Sumberdaya Lokal. 28 September 2011. Manokwari, ID. Bogor (ID): Balai Besar Pengkajian dan Pengembangan Teknologi Pertanian. Hal: 150-157.

Ling, K.C. 1979. Rice Virus Disease. IRRI. The Phillipines. 142p.

Merlin, dan A. Kasim. 2011. Pengkajian teknologi pengendalian penyakit tungro melalui introduksi galur/varietas unggul baru di Papua. Dalam Rauf A.W., R. Hendayana, E. Sutisna, Atekan, S. Ruku. SeminarNasional Akselerasi Pembangunan Pertanian dan Perdesaan Berbasis Inovasi dan Sumberdaya Lokal. 28 September 2011. Manokwari, ID. Bogor (ID): Balai Besar Pengkajian dan PengembanganTeknologi Pertanian. Hal: 158-162.

Pakki, S., dan A. Bastian. 2008. Dinamika sebatan penyakit tungro pada beberapa wilayah sentra produksi padi. Prosiding Seminar Ilmiah dan Pertemuan Tahunan PEI PFI XIX Komda Sulawesi Selatan, 5 Nopember 2008. Hal: 439-452.

Pakki, S. 2010. Peran faktor ekobiologi terhadap dinamika populasi vektor dan penyakit tungro. Prosiding Seminar Ilmiah dan Pertemuan Tahunan PEIPFI XX Komda Sulawesi Selatan, 27 Mei 2010. Hal: 107113.

Praptana, R.H., dan A. Burhanuddin. 2008. Keseuaian waktu tanam dan varietas dalam pengendalian penyakit tungro di Sulawesi Barat. Prosiding Seminar Ilmiah dan Pertemuan Tahunan PEI PFI XIX Komda Sulawesi Selatan, 5 Nopember 2008. Hal: 265-274.

Raga, I.N. 2008. Perkembangan dan penyebaran penyakit tungro di Indonesia. Prosiding Seminar Nasional "Strategi Pengendalian PenyakitTungroMendukung 
Peningkatan Produksi Beras". Makassar, 7-8 September 2007. Hal: 1-8.

Sama, S. 1985. Penerapan konsep pergiliran varietas dalam pengelolaan penyakit tungro. Makalah temulapang pengendalian penyakit tungro di Bayumas, 18-19 September 1985. 15 Hal.

Skelsey, P., W.A.H. Rossing, G.J.T. Kessel, J. Powell, and W. van der Werf. 2005. Influence of host diversity on development of epidemics: An evaluation and elaboration of mixture theory. Phyto-pathology 95: 328-338.

Suprihatno, B., A.A. Daradjat, Satoto, S.E. Baehaki, Suprihanto, A. Setyono, S.D. Indrasari, I.P. Wardana, dan H. Sembiring. 2010. Deskripsi varietas padi. Balai Besar Penelitian Tanaman Padi. Badan Litbang Pertanian. Kementerian Pertanian. 114 Hal.
Widiarta, I.N., Yulianto, dan M. Muhsin. 1997. Status penyebaran penyakit tungro pada padi di Jawa Barat. Jurnal Perlindungan Tanaman Indonesia 3: 23-31.

Widiarta, I.N., D. Kusdiaman, dan A. Hasanuddin. 1999. Dinamika populasi Nephotettix virescens pada dua pola tanam padi sawah. Jurnal Perlindungan Tanaman Padi 5 (1): 42-49. 